\title{
Triggered Activity によると思われる心室性不整脈
}

伊東盛夫*

\section{I .はじめに}

不整脈の発生機序として, reentry, 自動能 元進, および triggered activity が考えられ ている。臨床的不整脈においても患者の病態 によって, その発生機序は異なる可能性があ る. 不整脈の発生機序の同定は学問的興味だ けではなく, 適切な治療法の確立のためにも 重要である。近年, 臨床的不整脈と delayed afterdepolarization(DAD) から起こる triggered activityとの関係が注目されてい る1),31,7) 10,12). しかし, 現在のところ DAD か ら起こる triggered activityを他の機序から 鑑別する臨床的方法は確立されていない.も し，ある患者の不整脈の機序が DAD である ならば，その不整脈は実験的 DAD と同様な 特徵を示すと考えられる。このうな仮定に基 づいて，これまで triggered activityによる と思われる不整脈の同定が試みられてきた。

本稿では心室性不整脈と DAD の関係につ いて, 一部我々の成績を含めて, これまでの 報告を紹介する。

\section{II . DAD の電気生理学的特徵1),77,12)}

DAD は電気的弛緩期に起こる振動性の膜 電位の変化である. DAD が発生するために は, 少なくとも 1 個の活動電位が先行する必 要がある.DAD の振幅がある閾值に達する と伝導性の活動電位(triggered activity) が

* 大分医科大学臨床検查医学

( \%879-55 大分県大分郡挟間町医大ヶ丘 1-1)

S-2-22
発生する。 DAD は種々の条件下において発 生するが, これらの条件に共通する特徵は, 細胞内 $\mathrm{Ca}$ 濃度の上昇である7),10),12),18),19),24). なんらかの原因で細胞内 Ca イオン濃度が増 加すると, 筋小胞体には電気的弛緩期に $\mathrm{Ca}$ イオンの放出と再吸収を繰り返し行なう性質 が出現する.このような細胞内 $\mathrm{Ca}$ 濃度の周 期的変動が振動性の膜電流(transient inward current) を誘発し, DAD が発生する (図 1 ).

細胞内 $\mathrm{Ca}$ 濃度の上昇をきたし, DAD を誘 発・促進する要因・病態としては, ジギタリ ス中毒, 高頻度刺激, 細胞外 $\mathrm{K}$ 濃度の低下, 細胞外 $\mathrm{Ca}$ 濃度の上昇, カテコラミン投与, 交 感神経刺激, 虚血・再還流, 急性心筋梗塞な

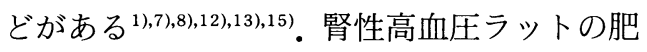
大心室筋や糖尿病ラットの心室筋は, 正常心 筋に比較して DAD を発生しやすい7).

DAD と triggered activityは種々の動物の Purkinje 線維, 心室筋, 心房筋, 房室弁, 冠 静脈洞，洞結節などの種々の心筇組織で記録 されている7),12),16),17),20). 哺乳動物の単離心室 筋細胞においても発生する ${ }^{24)}$. また, in vivo の動物の心室における triggered activity の 報告もある ${ }^{29), 32), 34)}$. 最近は, 接触電極法を用 いて monophasic action potential を記録す る方法により, in vivo の動物の心室からの DAD の記録が報告されている31),33). しかし 筆者の知るかぎりでは, 現在までのところ, 接触電極法により患者の心臓から DAD を記 録したという報告はない。

JPN. J. ELECTROCARDIOLOGY Vol. 14 SUPPL. 21994 


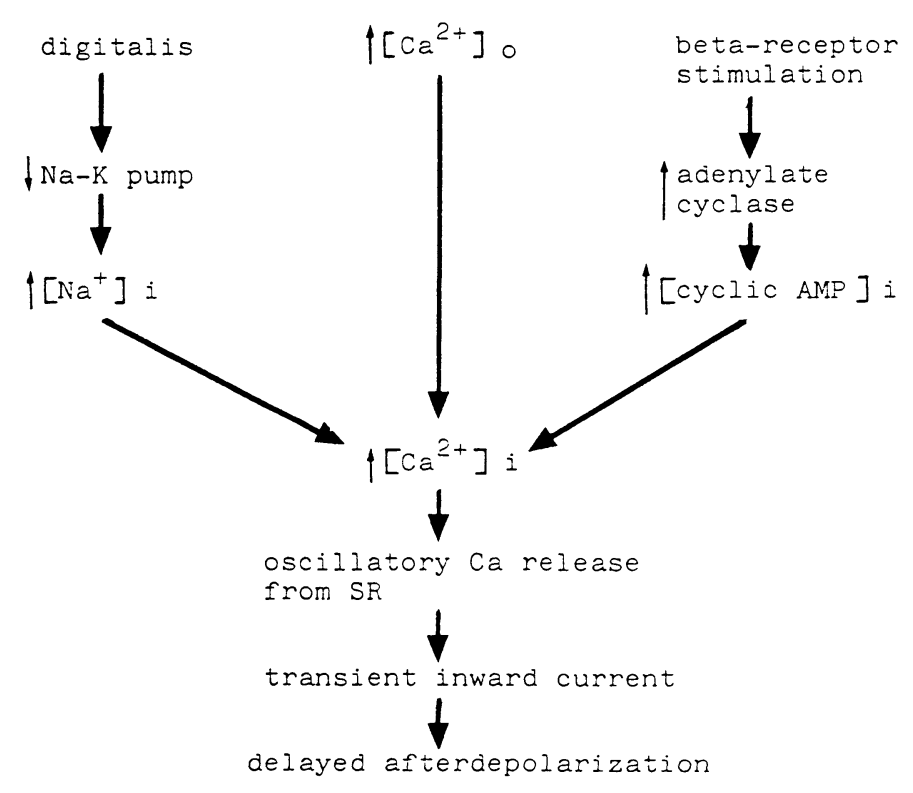

図 1 Delayed afterdepolarization の発生機序

（文献19），49）より改変引用）

以上述べたように，DAD と triggered activityは臨床的にも存在し得る種々の条件


の摘出標本でも記録されている。したがって, reentry や自動能と同様, DAD もまた臨床的 不整脈の発生に関与している可能性がある. DAD から起こる triggered activityの臨床 的同定において, 実験的 DAD の pacing およ び種々の薬物 (特に Ca 拮抗薬) に対する反応 が有用な指標として用いられている。

$\mathrm{DAD}$ の振幅は刺激頻度の増加とともに増 加し, triggered activity の閾值に達する確率 が増加する ${ }^{1), 3), 7), 28)}$. 刺激頻度の増加は $\mathrm{Ca}$ channel Æへして単位時間あたり流入する $\mathrm{Ca}$ 電流の増加をきたし, その結果, 細胞内 $\mathrm{Ca}$ 濃度が上昇し, DAD の振幅が増加するもの と考えられる.病的ヒト心房筋には自動能と $\mathrm{DAD}$ が共存し，自動能の rate の自然増加は 刺激頻度の増加の場合と同様, DAD の振幅 を増加をきたし, triggered activity を誘発す $ろ^{21)}$.

また，刺激頻度の増加は DAD の連結時間 の短縮をきたす1),3),7),28). 一方, reentry では,
先行刺激間隔の短縮は連結時間の延長をきた す3),6). この所見は DAD と reentry の重要な 鑑別点とされている.しかし, イヌ Purkinje 線維におけるジギタリス誘発性の triggered activity の連結時間は刺激間隔と逆相関を示 すこともある ${ }^{28)}$. また，病的ヒト心房筋で pacingにより誘発される triggered activity は, 刺激頻度の増大とともに, その rate は増 加するが連結時間は延長する ${ }^{30)}$.

$\mathrm{DAD}$ は刺激頻度のみならず，刺激の持続 時間(刺激の数)にも影響される。すなわち， 同じ刺激頻度でも，刺激の持続時間の延長と ともにDADの振幅は増加し, triggered activity の発生頻度が増加する (刺激の蓄積 効果) 1),7),99,16),20),26).

Triggered activity の持続的発生中に高頻 度刺激 (overdrive stimulation)加えると, 刺 激中止後, triggered activityの rate が促進 されるか (overdrive acceleration), あるいは activity は停止する ${ }^{7), 28)}$.

Slow channel を介して流入する Ca 電流 は細胞内 $\mathrm{Ca}$ 濃度の調節に重要な役割を果た しており, DAD は Ca 拮抗薬によって抑制さ 
れる7),11,22). $\mathrm{Mn}^{2+}$ は transient inward current と DAD を抑制するが，その時間経過を みると，まず slow inward current が減少し， それに続いて transient inward current の減 少が起こる ${ }^{19)}$. $\mathrm{Mn}^{2+}$ の wash out 後も, slow inward current $の$ 回復が transient inward current の回復に先行する。このような所見 は，Ca channel blocker による slow inward current の抑制-細胞内 $\mathrm{Ca}$ 濃度の減少-transient inward current の減少-DAD の抑制と いう過程を示唆する ${ }^{19}$. カテコラミンは DAD を誘発し，またジギタリス誘発性 DAD の振 幅を増大する ${ }^{4), 7), 25), 26), 35) ~}$.ベー夕遮断剂はカテ コラミンのこのような作用に拮抗する。また，
種々の $\mathrm{Na}$ channel blocker も DAD を抑制 する7),12),22).

\section{III. 心室頻拍 (VT)の発生における trigge- red activity の役割}

臨床的不整脈の発生機序の鑑別には, programmed electrical stimulation(PES)法と 体表面心電図の解析が用いられる。表 1 は PES に対する反応による不整脈の発生機序 の鑑別点をまとめたものである，不整脈の発 生機序として triggered activity が注目され る以前は，PES によって誘発・停止が可能な 不整脈は reentry が原因であり，これが不可 能な場合は自動能六進であると考えられてい

表 1 Pacing に対する反応による不整脈の機序の鑑別

\begin{tabular}{|c|c|c|c|}
\hline Criteria & Automaticity & Reentry & $\begin{array}{l}\text { Triggered } \\
\text { Activity } \\
\text { due to DAD }\end{array}$ \\
\hline \multicolumn{4}{|l|}{ Single Extrastimulus } \\
\hline Induces & - & +++ & + \\
\hline Terminates & - & +++ & + \\
\hline \multicolumn{4}{|l|}{ Multiple Extrastimuli } \\
\hline Induce & - & ++ & +++ \\
\hline Terminate & - & ++ & + \\
\hline \multicolumn{4}{|l|}{ Overdrive pacing } \\
\hline Induces & - & + & +++ \\
\hline Terminates & - & + & + \\
\hline Accelerates & - & - & ++ \\
\hline \multicolumn{4}{|l|}{$\begin{array}{l}\text { Relation of the interval between extrastimulus and last beat of } \\
\text { regular pacing and the coupling interval between extrastimulus } \\
\text { and 1st beat of induced rhythm }\end{array}$} \\
\hline Concordant & - & + & +++ \\
\hline Inverse & - & +++ & + \\
\hline \multicolumn{4}{|l|}{ Developement favored by } \\
\hline Rapid pacing & - & + & +++ \\
\hline Slow pacing & + & + & --- \\
\hline $\begin{array}{l}\text { Increasing pacing rate increases the rate and the number of } \\
\text { induced responses }\end{array}$ & - & $?$ & +++ \\
\hline Initiation depends on number of stimuli & - & + & +++ \\
\hline
\end{tabular}


た.しかし, triggered activityも reentry と 同様，PESよって誘発・停止が可能であり， 両者の鑑別は臨床上困難な問題であ $ろ^{3), 6), 7), 12), 28)}$.

以下, DAD から起こる triggered activity とVTとの関連について検討した臨床報告 のいくつかを紹介する.

Burgada ら ${ }^{6}$ は PES 法を用いて, VTの機 序が reentry か triggered activity かを検討 した。陳旧性心筋梗塞 (120例) と right ventricular dysplasia( 8 例)の全例において, pacing によるVT の誘発・停止が可能であっ た。また，運動負荷誘発性特発性 VT の 8 例 中 4 例で, pacingによるVT の誘発・停止が 可能であった。これらの症例のうち, 刺激間 隔とVT の連結時間(最後の刺激とVT の 1 発目の間隔)が正相関を示したのは特発性 VTの 2 例のみであった。

Ohe ら ${ }^{47)}$ は, 上室性頻拍とVTのPESに 対する反応を比較した. WPW tachycardia (148例), 房室結節性 reentrant tachycardia (52例), 陳旧性心筋梗塞 (11例) と拡張型心筋 症 (12例) のVT，および特発性持続性 VT の 患者(15例)では, PES による頻拍の誘発・停 止が可能であり，かつ連結時間が正相関を示 したものは 1 例もなかった. 一方, 特発性反 復性 VT 例では PES によるVT の誘発が可 能であった例は 28 例中 4 例にすぎず，この 4 例ではVTの連結時間は正相関を示した。こ れらの成績はVTの機序は主として reentry であるが，特発性VTの一部に triggered activity が関与している可能性を示唆する.

Sung ら ${ }^{40)}$ はT の PES と verapamil に 対する反応によって21例のVT の機序の鑑 別を試みた. その結果, PES によるVTの誘 発と停止が可能で刺激間隔とVTの連結時 間が逆相関を示すもの (11例, reentry), PES によるVTの誘発が不可能で, isoproterenol 静注により誘発されるもの(自動能, 7 例), および期外刺激ではVT が誘発されず, 高頻 度刺激で誘発され, VT の連結時間が正相関
を示すもの (triggered activity， 3 例)の 3 群 に分類できた. Verapamil は triggered activity と推測された 3 例のVTに対してのみ抑 制効果を発揮した。

DAD は Ca channel 依存性の現象であり, $\mathrm{Ca}$ 拮抗薬により抑制される7),22). しかし $\mathrm{Ca}$ 拮抗薬は DAD 以外の機序による不整脈も抑 制し得る ${ }^{5), 11}$. Kasanuki ら ${ }^{48)}$ は PES 法によ り, verapamil-sensitive な特発性 VT の14 症例を検討し，10例は reentry，3 例は triggered activity，1例は自動能であると推測し た. Ohe ら ${ }^{56)}$ によれば, 右脚ブロック型で左軸 偏位の QRS 波形を示す VT は verapamilsensitiveであるが，PES に対する反応から は reentry が機序と考えられる。

左脚ブロック型下方軸の QRS 波形を示す VT と triggered activityの関係が注目され ている. Ritchie ら ${ }^{59}$ は, 左脚ブロック型下方 軸の QRS 波形を示すVT の症例は，それ以 外の QRS 波形の VT 例に比較して心疾患の ない若年者が多く, isoproterenol 静注や運動 負荷によるVT の誘発率が高く, PES による 誘発率は低いなどの特徵を示した。彼らは左 脚ブロック型下方軸の QRS を示す VT の機 序はDADであろうと推測している59).

Zimmermann ら ${ }^{50)}$ は, 24時間心電図法を用 いて, 反復性単形性特発性 (repetitive monomorphic idiopathic) VT の30例を検討 した。ほとんどの症例において心疾患の合併 を認めず, VT の QRS 波形は正常軸または右 軸偏位の左脚ブロック型を示した。24時間心 電図記録のコンピュータ解析により, VT と 先行 RR 間隔の関係を分析し，心室性不整脈 の連発数は, 次の三つの計測值と正相関する ことを認めた. (1)先行する 3 分間の平均心拍 数, (2)不整脈発生の直前の RR 間隔, および (3)不整脈の連結時間である.Zimmermann ら は，(1)の所見とこれらのVTに対する verapamil の有効性などの所見は DAD に類似す るが, (2)と(3)の所見は, 徐脈依存性の early afterdepolarization との関連をも示唆する 
と考察している ${ }^{50)}$.

左脚ブロック型下方軸の QRS 波形を示す VT の起源は右室流出路と考えられる ${ }^{65)}$. Mitrani ら ${ }^{671}$ は, 右室流出路起源のVTと DAD の関連を検討するために, 右室流出路 における ablation 成功部位の近傍から接触 電極法を用いて monophasic action potential を記録した，検討した 6 例のうち 1 例か ら early afterdepolarization が記録された が, 残りの 5 例からは early afterdepolarization あるいは DAD のいずれも記録できなか った. 彼らは, 右室流出路起源のVTは通常 は afterdepolarization 以外の機序によるも のであろうと考察している ${ }^{67)}$.

運動負荷により誘発されるVTに対して, $\mathrm{Ca}$ 拮抗薬とベー夕遮断剂が有効であり, DAD との関連が推測されている36),38),431,44). Lerman $ら^{49), 66) や W i l b e r ~} ら^{65)}$ は, adenosine によって抑制される運動誘発性 VT の症例 を報告している。これらの症例のほとんどは 器質的心疾患のない若年者であり, VTは左 脚ブロック型下方軸(右室流出路起源)を示す ものが多い.VTは isoproterenolにより誘 発・促進され, verapamil や propranolol が有 効である.PESによりVT の誘発・停止が可 能であったが, VT の連結時間と刺激間隔は
一定の相関を示さなかった. Adenosine は心 室筋に対しなんらの直接的電気生理学的作用 を有しない ${ }^{14)}$. ベータ受容体刺激は細胞内 cyclic AMP を増加させ, Ca overload をきた してDADを誘発する(図 1 ). Adenosine の 心室筋に対する唯一の作用は, ベー夕受容体 の刺激による細胞内 cyclic AMP の増加を抑 制することである ${ }^{14), 49)}$. Adenosine はreentry や自動能立進には無効である ${ }^{14), 49), 66)}$. ジギタリスや細胞外 $\mathrm{Ca}$ 濃度の上昇などによ る, cyclic AMP を介さない DAD に対しては adenosine は無効である ${ }^{14)}$. Lerman らは, adenosineによるVTの抑制はVTの機序 として cyclic AMP-mediated triggered activity 強く示唆する所見であると主張し ている ${ }^{49), 66)}$.

このほかにも，VTとDADの関連につい て検討した報告は多数みられる. 表 2 に PES と各種の薬剤に対する VTの反応に基づい て, DAD から起こる triggered activity と推 測されたVT の症例のリストを示す．報告者 によって患者の選択基準，および triggered activity と推測した根拠が異なる.しかし,こ れらの症例にはある共通点がみられる。すな わち, 明らかな器質的心疾患のない比較的若 年者における運動誘発性 VTであることで

表 2 Triggered activity に由来すると思われる心室頻拍 (VT)

\begin{tabular}{|c|c|c|c|c|c|c|}
\hline 報告者(発表年) & 症例数 & 年 齢 & $\begin{array}{l}\text { 性 別 } \\
\text { 男 / 女 }\end{array}$ & $\begin{array}{l}\text { 心疾患 } \\
\text { 無 / 有 }\end{array}$ & $\begin{array}{c}\mathrm{VT} \text { の波形 } \\
\mathrm{LBBB} / \mathrm{RBBB}\end{array}$ & 連結時間 \\
\hline Zeipes $(1979)^{36)}$ & 1 & 22 & $1 / 0$ & $1 / 0$ & $1 / 0$ & ? \\
\hline $\mathrm{Wu}(1981)^{38)}$ & 3 & $33 \sim 53$ & $3 / 0$ & $3 / 0$ & $3 / 0$ & ? \\
\hline Sung $(1983)^{40)}$ & 3 & $18 \sim 32$ & $2 / 1$ & $3 / 0$ & $2 / 1$ & 正相関 \\
\hline Shenoy $(1986)^{46)}$ & 1 & 13 & $1 / 0$ & $0 / 1$ & $0 / 1$ & ? \\
\hline Lerman $(1986)^{49)}$ & 4 & $25 \sim 32$ & $3 / 1$ & $4 / 0$ & $4 / 0$ & 相関なし \\
\hline 平 岡 $(1986)^{9)}$ & 1 & 43 & $0 / 1$ & $1 / 0$ & $1 / 0$ & 正相関 \\
\hline 藤 井 $(1987)^{53)}$ & 1 & 17 & $1 / 0$ & $0 / 1$ & $0 / 1$ & 相関なし \\
\hline Bhandari (1988) ${ }^{55)}$ & 1 & 28 & $1 / 0$ & $1 / 0$ & $0 / 1$ & 正相関 \\
\hline Wilber(1993) ${ }^{65)}$ & 7 & $23 \sim 53$ & $3 / 4$ & $7 / 0$ & $7 / 0$ & ? \\
\hline Lerman (1993) ${ }^{66)}$ & 8 & $17 \sim 77$ & $6 / 2$ & $6 / 2$ & $7 / 1$ & $?$ \\
\hline total & 30 & $13 \sim 77$ & $21 / 9$ & $26 / 4$ & $25 / 5$ & \\
\hline
\end{tabular}

$\mathrm{LBBB} / \mathrm{RBBB}=\mathrm{VT}$ の $\mathrm{QRS}$ 波形が左脚ブロック型/右脚ブロック型, 連結時間=誘発され たVTの連結時間と先行刺激間隔の関係，?=記載なし 
ある. 表 3 に示す 30 例の平均年齢は 36 歳で, 心疾患の合併率は $13 \%$ である。これらのVT の QRS 波形は下方軸の左脚ブロック型を示 すものが多い. Isoproterenol はVTを誘発 しまた PESによるVT の誘発を促進する。 これらの VTは verapamil, propranolol, あ るいは adenosineにより抑制される。刺激間 隔とVTの連結時間の正相関が triggered activity の重要な判定基準の一つとされてい $3^{9), 40,55)}$. しかし, 一定の相関を示さない例 や49,53), PES によるVT の誘発が不可能な例 もみられる ${ }^{38)}$.

冠動脈疾患やその他の心疾患のない症例に おける運動誘発性 VT の発生には, 運動に伴 う心拍数の増加と交感神経緊張(カテコラミ ン)が関与しているものと推測される。刺激頻 度 (心拍数)の増加とカテコラミンのいずれも DAD を誘発・促進する4),7),12),35).このほか $\mathrm{DAD}$ を誘発・促進する条件としてジギタリ 又投与, 低 $\mathrm{K}$ 血症, 高 $\mathrm{Ca}$ 血症, 低 $\mathrm{Mg}$ 血症, 心筋虚血, 再灌流, 心筋梗塞, 心不全などが ある ${ }^{1), 7), 8), 12), 13), 15)}$. このような臨床的条件にお いては triggered activityによる心室性不整 脈が発生する可能性がある。

\section{DAD に由来すると思われる心室性期外収縮 (VPC)の同定：24時間心電図法による検討} 体表面心電図の解析は不整脈の発生機序に ついて有用な情報を与える. PES は invasive
な方法であり，患者によっては実施困難な場 合もある. Reentry と同様に triggered activityも, PESによって誘発・停止が可能であ る6),7),12),28). しかし, triggered activity は reentryに比較してPESによる誘発率が低 (12),28). PES 法はVT の引金となる VPCの 発生機序の検討はできない. VPCとVTの 発生機序は必ずしも同じではない可能性もあ る ${ }^{42)}$. 体表面心電図法は noninvasive な方法 であり, PES で誘発困難な不整脈の検討 や50), VT の引金となる VPC の機序の解析に 有用である41),45),52),57). Rosen ら ${ }^{37)}$ は accelerated atrioventricular junctional escape rhythm の心電図記録の RR 間隔を計測し, この不整脈は DADの機序によって説明可能 であると報告している。

我々は,これまでDAD から起こる triggered activityによると思われるVPCを，24時 間心電図法を用いて同定することを検討して きた ${ }^{45), 51), 52), 54), 60), 64)}$. 以下, 我々の成績を紹介 する.

もし, VPC の発生機序が DAD であるなら ば,その VPC は実験的 DAD と同様の特徴を 示すと考えられる。このような観点に立って DAD に比較的特徵的で, かつ 24 時間心電図 法によって検討可能な所見を選び，これを指 標として DAD から起こる triggered activityに由来すると思われるVPCの同定を試 みた.表 3 に我々が用いた triggered activity

表 3 Delayed afterdepolarization(DAD)によると思われる心室性期外収縮(VPC)の判 定基準

実験的 DAD の特徵

1. 刺激頻度の増加とともに DAD の振幅が増加する.

2. 刺激頻度の増加とともに DAD 連結時間が短縮する。

3 . 刺激の持続時間の延長とともに DAD の振幅が増加する.

4. DAD は Ca 拮抗薬により抑制される.

$\mathrm{DAD}$ に由来するVPC の特徵

1. 心拍数の増加とともにVPCの発生頻度が増加する.

2. 心拍数の増加とともにVPCの連結時間が短縮する.

3. 心拍数増加の持続時間の延長とともにVPCの発生頻度が堌加する.

4.VPC は Ca 拮抗薬により抑制される. 
の判定基準を示す。

\section{VPC の発生頻度と心拍数の関係}

$\mathrm{DAD}$ の振幅は刺激頻度の増加とともに増 加し, triggered activity の閾値に達する確率 が増加する11,3),7),28). したがって triggered activity によるVPC の発生頻度は, 心拍数の 増加とともに増加するものと期待される(表 3, 判定基準 1 )。
そこで，我々は24時間心電図記録のコンピ ュータ解析によりVPC の発生頻度と心拍数 の関係(VPC-HR 関係)を検討した ${ }^{45), 51), 52), 54)}$. VPC-HR 関係は Winkle の方法 ${ }^{39}$ に準じた 方法で解析した。

VPC を頻発する68例について検討した成 績を示す ${ }^{54)}$. 24時間心電図は約 2 週間の間隔 で 2 回記録した。いずれの記録も 1 週間以上

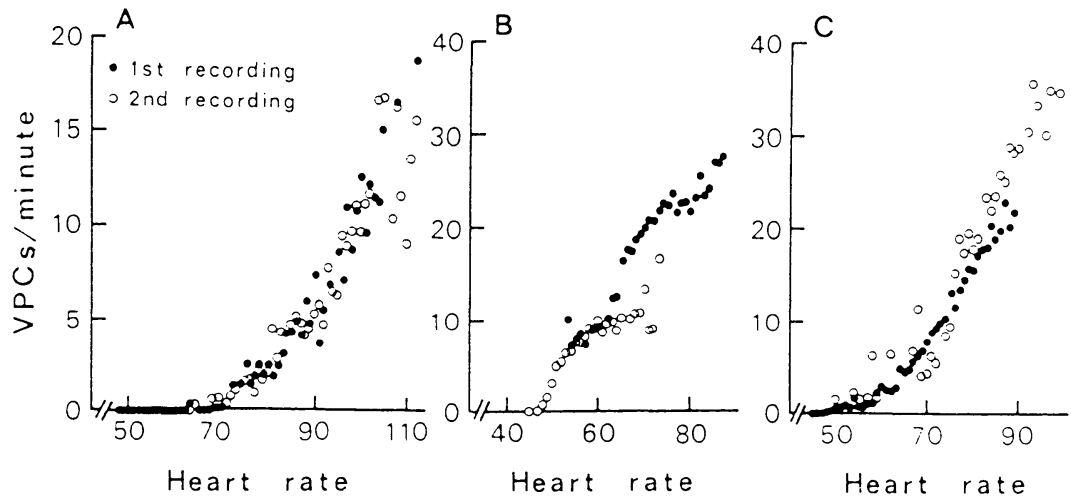

図 2 心室性期外収縮 (VPC) 頻度と心拍数の関係 (促進型)

1 回目の 24 時間心電図記録(黒丸)に対する 2 回目の記録(白丸)の VPC 総数と平均心拍数 の変化率は，A はー8\%と $1 \% ， \mathrm{~B}$ は $-55 \%$ と - 15\%，C は $119 \%$ と $13 \%$ 。

(文献54)より引用)
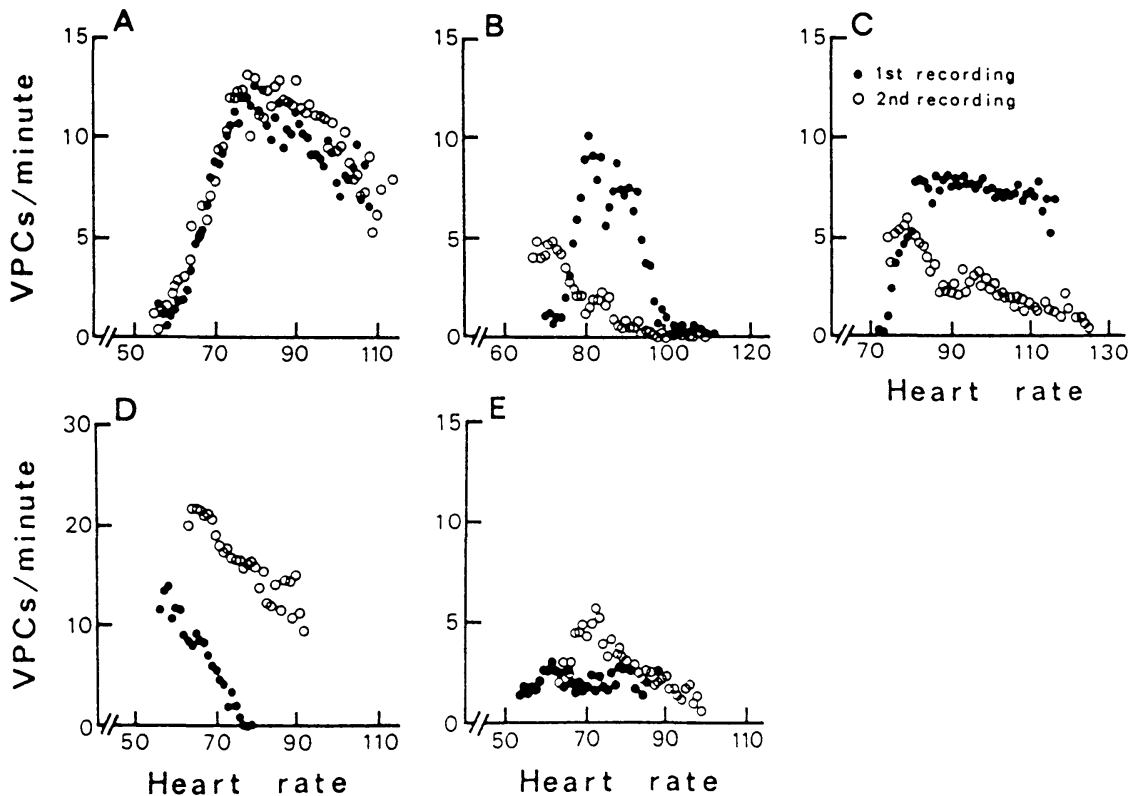

Heart rate

図 3 VPC 頻度と心拍数の関係(非促進型)

黒丸と白丸はそれぞれ 1 回目と 2 回目の 24 時間心電図記録のデータ.（文献54）より引用) 
抗不整脈剤の投与を中止後に行なった.VPC -HR 関係は患者によってさまざまなパター ンを示したが, そのパターンは次の 4 型に大 別できた。(1)心拍数の増加とともにVPCが 増加(positive correlation, 促進型, 26例, 図 2, 黒丸), (2)低心拍数領域では VPC が増加 し, 高心拍数領域で減少 (bidirectional correlation, 促進・抑制型, 38例, 図 $3 \mathrm{~A} \sim \mathrm{C}$, 黒 丸), (3)心拍数の増加とともに VPC が減少 (negative correlation, 抑制型, 2 例, 図 3 D, 黒丸), (4)全心拍数の領域で VPC 頻度がほ ぼ一定 (flat correlation, 平坦型, 2 例, 図 3 $\mathrm{E}$, 黒丸). 我々は VPC-HR 関係を促進型と それ以外の非促進型の 2 型に大別した。

VPC-HR 関係のパターンは高い再現性を 示した ${ }^{54)}$. 1 回目の 24 時間心電図記録におい て促進型を示した26例中25例(96\%) が 2 回目 も促進型を示した(図 2 )。また，1 回目に非 促進型を示した42例中40例 (95\%) が 2 回目も 非促進型を示した(図 3 ).

図 4 は 2 回の 24 時間心電図記録の間に抢け る VPC 総数の変化率(縦軸) と 1 日平均心拍 数の変化率(横軸)の関係をプロットしたもの であり, 促進型 (図 $4 \mathrm{~A}$ ) と非促進型 (図 $4 \mathrm{~B}$ )
のいずれも有意の正相関を示した。しかし， 相関係数は促進型 $(\mathrm{r}=0.80)$ の方が非促進型 $(r=0.34)$ より有意に大であった. 2 回の 24 時 間心電図記録における VPC-HR 関係のグラ フを比較すると，促進型では VPC-HR 関係 の勾配はほとんど変化しない例が多かった (26例中 20 例，77\%，(図 2))。すなうち，1日 の VPC の発生頻度と平均心拍数は種々の程 度の自然変動を示すが，ある心拍数における VPC 頻度はほぼ一定に保持されることを示 す。一方，非促進型では 2 回の記録の VPC$\mathrm{HR}$ 関係のグラフが上下あるいは左右にずれ を示す例が多くみられた(図 $3 \mathrm{~B} \sim \mathrm{F}, 42$ 例中 28例，67\%). 以上のような成績は, 特に促進 型VPCにおいては心拍数の日差変動が VPC 総数の自然変動の重要な決定因子であ ることを示唆する.

心拍数増加とともにその発生頻度が増加す る促進型 VPC は, DAD から起こる triggered activity の特徴に類似している.しかし, VPC-HR 関係のみによって，不整脈の発生 機序を鑑別することは困難であることはいう

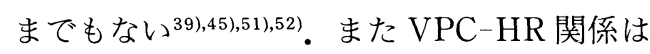
日常生活中の心拍数変動の範囲での観察であ
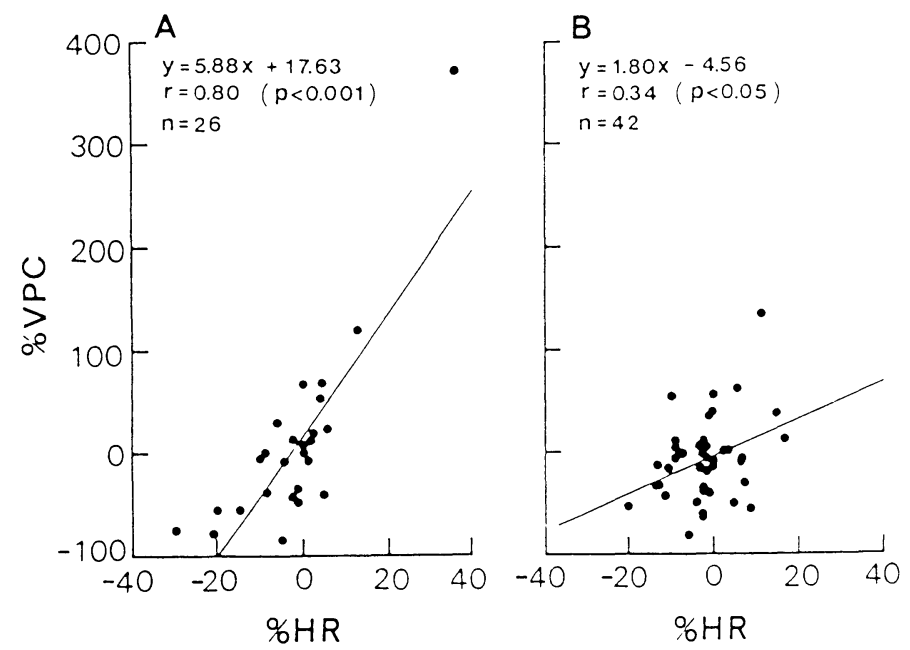

図 41 回目の24時間心電図記録に対する 2 回目の記録の 1 日平均心拍 数と VPC 頻度の変化率の相関関係

A：促進型 (26例), B：非促進型 (42例).

（文献54）より引用） 
る. 運動負荷などにより最大心拍数を著明に 増加させれば, VPC-HR 関係のパターンも 変化する可能性がある ${ }^{611}$.

\section{2. 心拍数とVPC の連結時間の関係}

$\mathrm{DAD}$ の連結時間は刺激頻度の増加ととも に短縮する ${ }^{1,33,6,77), 28)}$ 。したがって triggered activityによる VPC の連結時間は心拍数の 増加とともに短縮するものと期待される(表 3 , 判定基準 2 ).

我々はVPC を頻発する132例の VPC の連 結時間と心拍数の関係 (CI-HR 関係) を解析 した ${ }^{60)}$.これらの症例の VPC-HR 関係は促 進型43例 (33\%，図 5 A). 非促進型89例 (67 \%, 図 5 B〜D)であった. CI-HR 関係はほと んどの症例（132例中123例，93\%）で有意の負 相関を示した。有意の正相関は 1 例 ( $1 \%$ ) に のみ認め, 残りの 8 例 $(6 \%)$ では有意の相関 を認めなかった. CI-HR 関係の勾配は，促進 群と非促進群の間に有意差はなかった

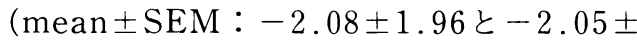
$1.90 \mathrm{msec} /$ beats $/ \mathrm{min}$ ).

これまでの 24 時間心電図記録の分析におい ても，先行 RR 間隔の短縮とともにVPCの 連続時間は短縮する例がほとんどであると報
告されている57). 以上のような成績は, 日常生 活中の心電図記録では VPC の機序にかかわ らず，その連結時間は心拍数の増加とともに

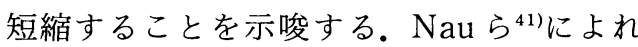
ば，運動負荷あるいは心房ペーシングによっ て同程度の心拍数増加をきたした場合，運動 負荷の方が VPC の連結時間は短い. その機 序は不明であるが, 運動負荷に伴う交感神経 緊張が連結時間の短縮をきたす可能性がある. 心拍数増加それ自体は伝導を抑制して連結時 間を延長させるが, 交感神経緊張は伝導を促 進して連結時間を短縮させ, 結果として, 心 拍数増加に伴い連結時間は短縮するとの説明 も可能である ${ }^{41), 60)}$.

促進型 VPC については心拍数の増加とと もに発生頻度が増加し，連結時間が短縮する という所見は DAD の特徵に一致する。なぜ ならば，心拍数 (刺激頻度)の増加と交感神経 緊張の両者は細胞内 $\mathrm{Ca}$ 濃度の増加をきたし, その結果 DAD の振幅の増加と連結時間の短 縮をきたすからである(4),7),18),24).

\section{3．VPC に対する抗不整脈刘の効果}

もし VPC の機序が DAD であるならば,そ の VPC は Ca 拮抗薬によって抑制されるこ
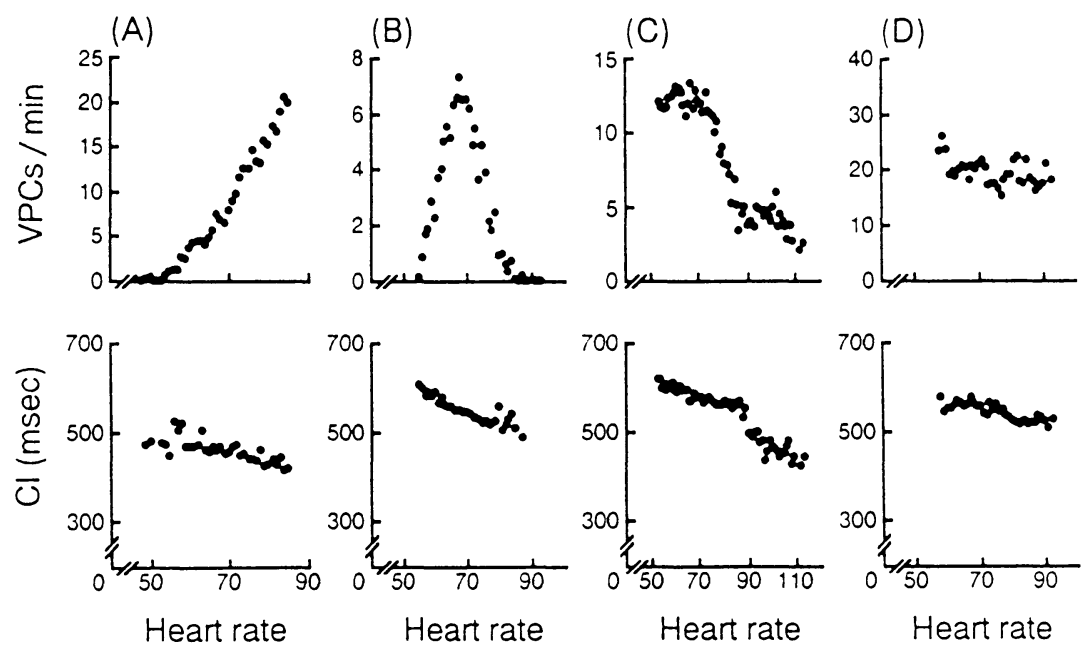

図 5 VPC 発生頻度 (上段)，およびVPC の連結時間 $(\mathrm{Cl})$ (下段)と心拍数との関係 促進型 $(\mathrm{A})$ と非促進型 (B-D)のいずれにおいても, 心拍数増加とともに VPC の連結時間が 短縮した。

(文献60)より引用) 
とが期待される(表 3，判定基準 4 )。これま で上室性不整脈や VT に対する Ca 拮抗薬の 臨床効果についての報告は多いが, VPCにつ
いての報告は少ない ${ }^{11)}$. 我々は diltiazem の VPC に対する抑制効果を VPC-HR 関係と 対比検討した ${ }^{45), 51), 522,64)}$.

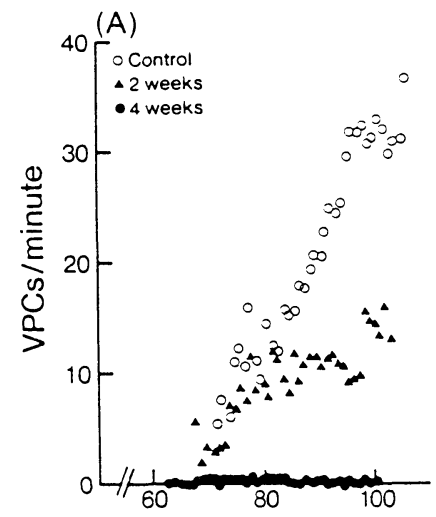

Heart rate



Heart rate

図 6 促進型 VPC に対する diltiazem の効果

$\bigcirc, \boldsymbol{\Delta}$, はそれぞれ治療前, 治療後 2 週間目および 4 週間目のデー夕. Diltiazem 治療後, VPC 類度と心拍数の関係の勾配が減少し, それととも にVPC 総数が減少した.

(文献51)より引用)
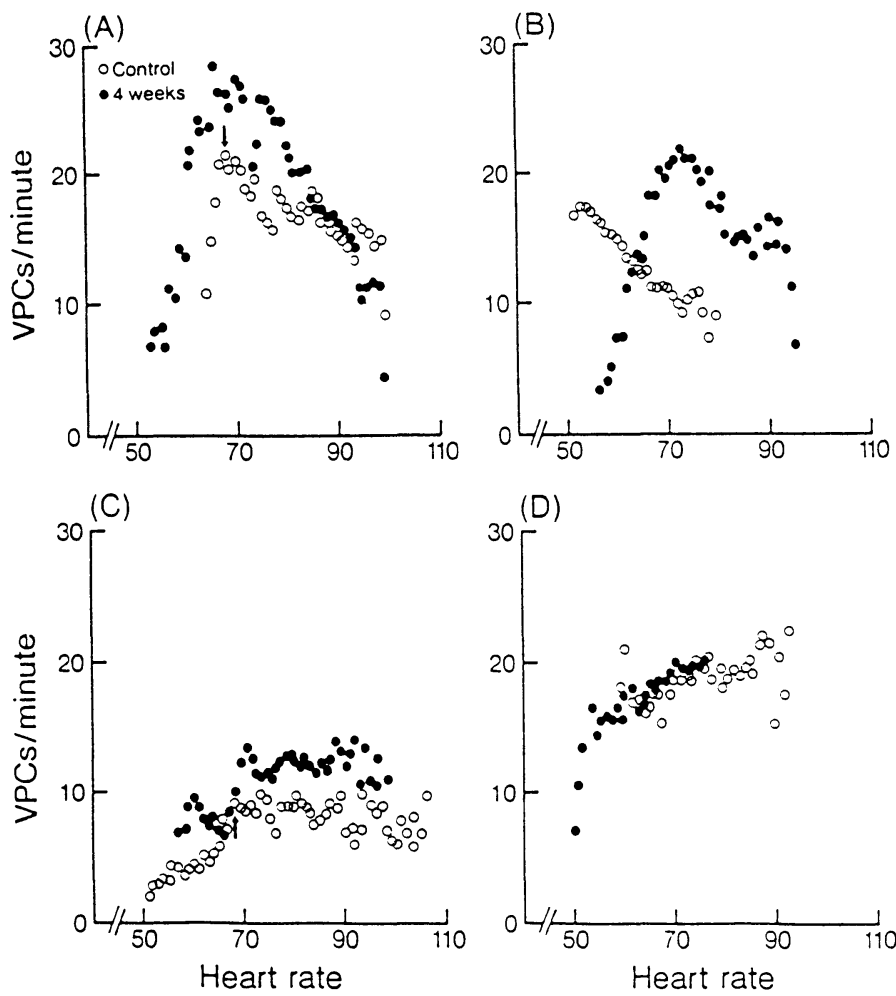

図 7 非促進型 VPC diltiazem の効果

○と○はそれぞれ治療前と治療後 4 週間目のデー夕.（文献51）より引用） 
VPC を頻発する36例についての成績を述 べる ${ }^{51)}$. 36例の VPC-HR 関係は促進型16例 (図 6 )，非促進型20例(図 7 )であった。Diltiazem (90〜180mg/日， 4 週間経口投与) は促 進型の VPC 数と心拍数を有意に減少したが, 非促進型には有意の変化をきたさなかった (図 8 ). Diltiazem 投与後， $70 \%$ 以上の VPC 減少をきたしたものは促進群16例中 9 例であ ったのに対し，非促進群では20例中 1 例のみ であった $(\mathrm{p}<0.01$ ，図 9$)$.

Diltiazemにより促進型 VPC が抑制され たという所見は実験的 DAD の特徵と類似し ている.しかし, reentry 性の不整脈や部分的 に脱分極した膜電位からの異常自動能に対し ても, $\mathrm{Ca}$ 拮抗薬は抑制効果を発揮し得 $3^{5,, 11), 48), 56)}$.

さらに，我々は促進型と非促進型の VPC に対するベー夕遮断剤 atenolol (50mg/日, 4 週間経口投与)の効果を比較検討した ${ }^{51)}$. Diltiazem と同様に atenolol はほとんど促進 型のVPCのみを抑制した(図10～図12). Diltiazem と atenolol の効果を比較すると,
(A)
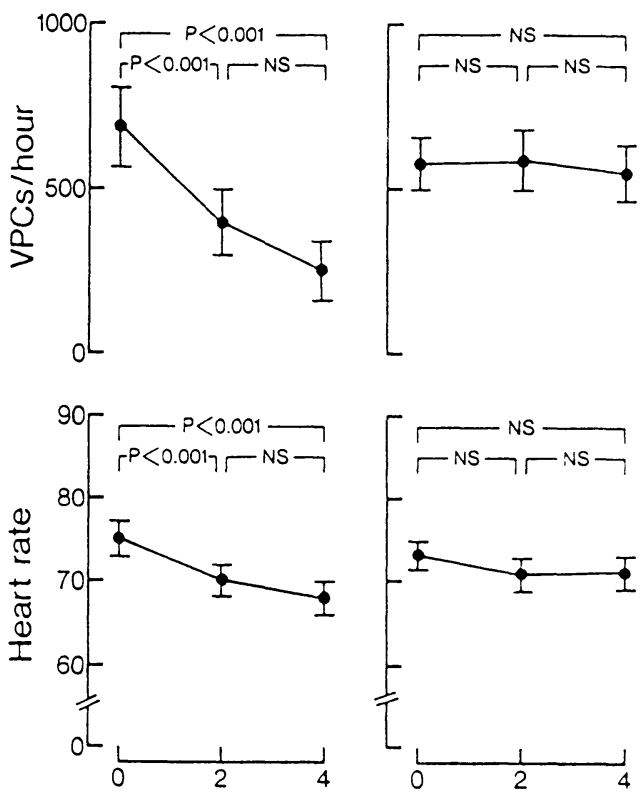

Duration of diltiazem therapy (week)

図 8 VPC 頻度 (上段)と 1 日平均心拍数 (下段) に対 する diltiazem の効果

A は促進群(16例)，B は非促進群(20例)。デー夕は mean \pm SEM

(文献51)ょり引用)
(A)



(B)

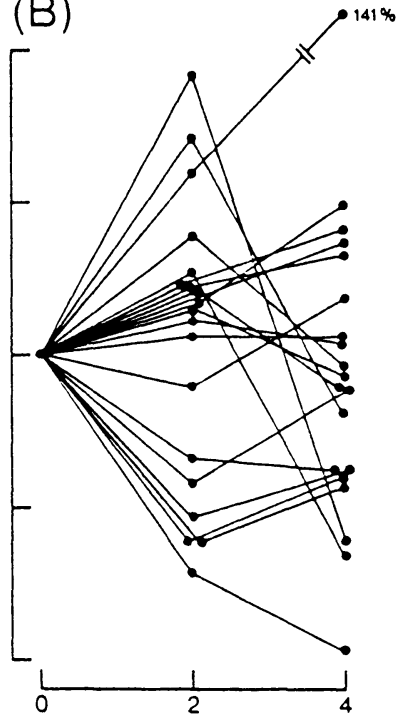

Duration of diltiazem therapy (week)

図 9 Diltiazem 治療によるVPC 頻度の变化率 

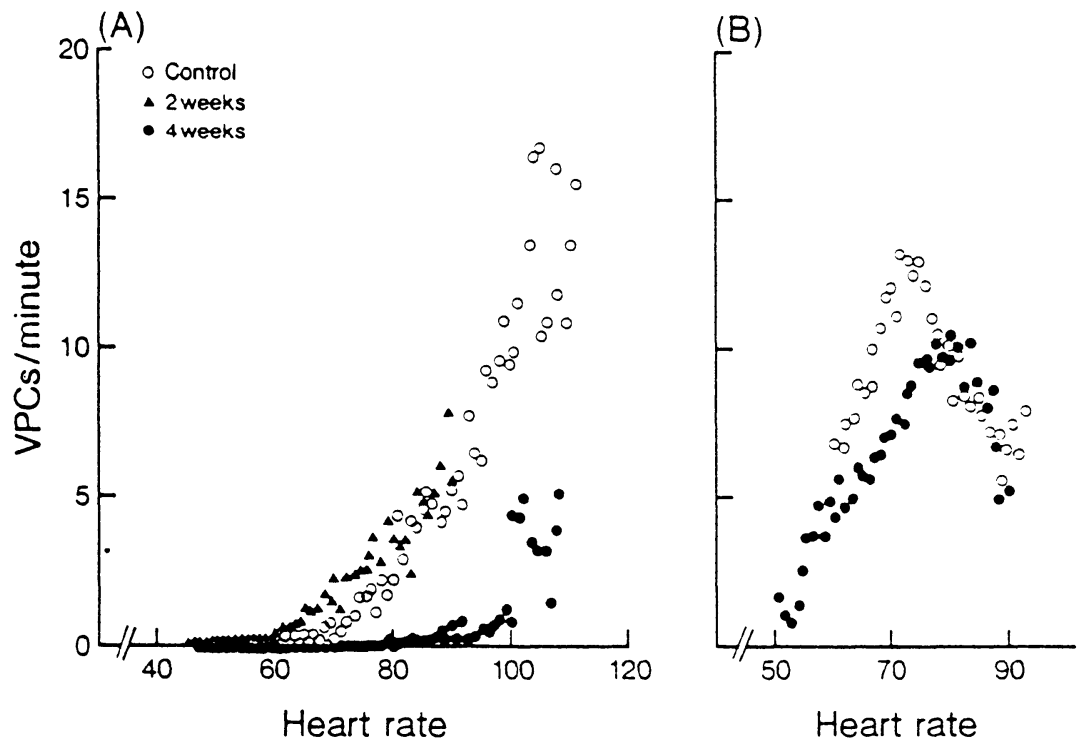

図10 Atenolol 投与によるVPC 頻度と心拍数の関係の変化

○，、， ○それぞれ投与前と投与後 2 週間目および 4 週間目のデータ. A は促進型. 2 週間目には, 最大心拍数が著明に減少したが, VPC と心拍数の関係のグラフの勾配はほと んど不変であり，4 週間目に勾配が減少した。B は非促進型.

(文献51)より引用)

いくつかの類似点と相違点がみられた．類似 点としては両薬剤とも非促進型よりも促進型 VPC に対して抑制効果が大であり，かつ，投 与期間が 2 週間から 4 週間へと延長するに伴 い促進型の VPC の減少も進行した（図８，図 9, 図11, 図12)。一方, 両薬剤の促進型 VPC に対する効果は次のような相違を示した。 心 拍数減少作用は diltiazem(図 8,下段)より も atenolol の方が大であった(図11，下段). また diltiazem 治療では 2 週間目に促進型 VPC-HR 関係の勾配が減少し，4 週間目に はその減少はさらに進行した(図6)。一方， atenolol 治療では，2 週間目には最大心拍数 は著明に減少したが，VPC-HR 関係の勾配 はほとんど不変であり，4 週間目に初めて勾 配が減少した(図10 A).

促進型 VPC-HR 関係の勾配の減少は，あ る心拍数におけるVPCの発生頻度の減少を 示す。同じ刺激頻度で比較した場合，細胞内 $\mathrm{Ca}$ 濃度が高い場合は低い場合よりも，DAD の振幅が大であり, triggered activity の発生 頻度が大であると考えられる。したがって，
(A)

(B)
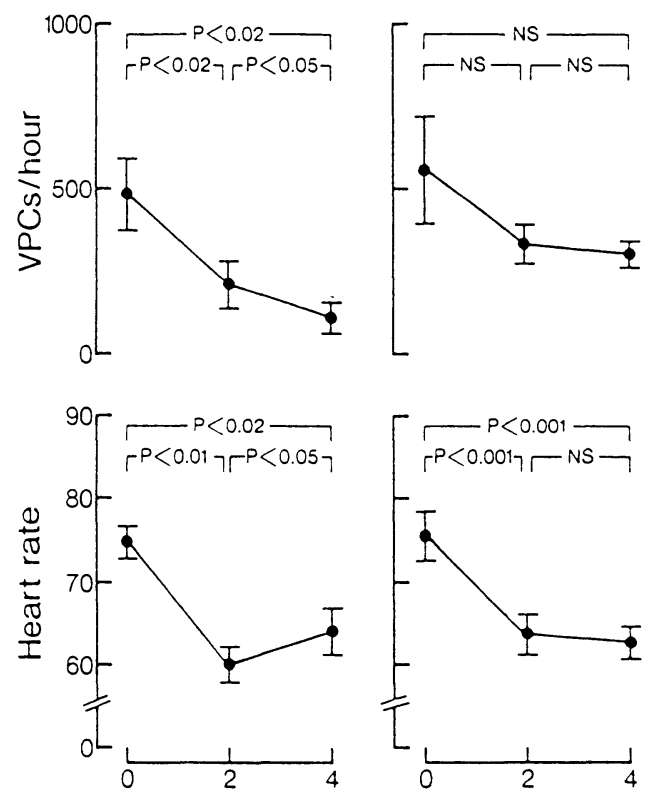

Duration of atenolol therapy (week)

図11VPC 頻度 (上段) と 1 日平均心拍数 (下段) に対 する atenolol の効果

$\mathrm{A}$ は促進群 ( 6 例), B は非促進群(10例)。デー夕は mean \pm SEM

(文献51)より引用) 
(A)

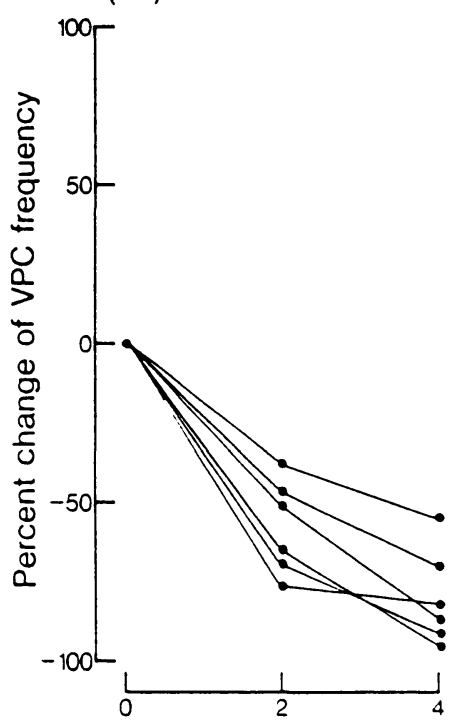

(B)

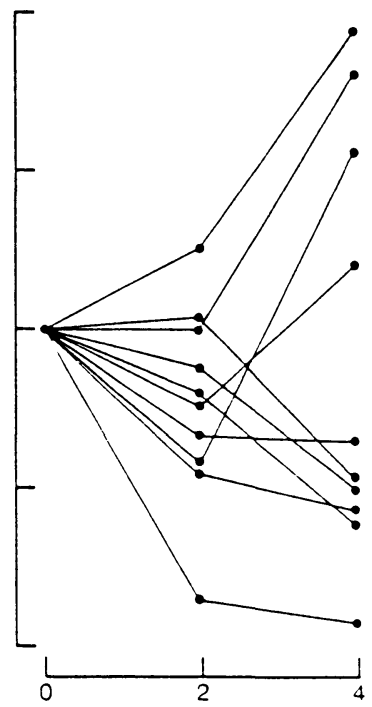

Duration of atenolol therapy (week)

図12 Atenolol 治療による VPC 頻度の変化率

$\mathrm{A}$ は促進群, B は非促進群.

(文献51)より引用)

もし促進型 VPC の機序が DAD であるなら ば, VPC-HR 関係の勾配は細胞内 Ca 濃度の 指標と考えられる.Ca 拮抗薬は Ca channel を介して流入する $\mathrm{Ca}$ 電流を抑制し, 細胞内 $\mathrm{Ca}$ 濃度を減少させることにより DADの振 幅を抑制し, その結果, 促進型 VPC-HR 関係 の勾配が減少したとの説明も可能である.

一方, atenolol 投与では 2 週間目には最大 心拍数は著明に減少したが, 促進型 VPCHR 関係の勾配は不変であった (図10 A)。こ の変化はVPC と心拍数の自然変動における 所見と類似している(図 2 B). したがって, atenolol 投与 2 週間目にみられた促進型 VPC 減少の主なる要因は心拍数減少それ自 体であると推測される. Atenolol 投与 4 週間 目に促進型 VPC-HR 関係の勾配が減少した 機序として, atenololによる持続的心拍数減 少が，単位時間あたり Ca channel を介して 流入する $\mathrm{Ca}$ 電流を減少させ, 細胞内 $\mathrm{Ca}$ 濃度 が減少したことが考えられる.また, atenolol が, ベー夕受容体刺激による細胞内 cyclic
AMP の濃度の増加を抑制して Ca 電流を減 少させ, その結果, 細胞内 $\mathrm{Ca}$ 濃度が減少した という可能性も考えられる(図 1 )。

小林ら ${ }^{62)}$ は, verapamil とベー夕遮断剂が 有効な促進型 VPC が, adenosine の細胞内吸 収阻害剤である dipyridamoleによっても抑 制されたと報告している. Lerman らは, adenosine-sensitiveな VT は dipyridamole によっても抑制されることを報告し，このよ うなVTの機序は cycllic AMP-mediated triggered activity であろうと推測してい る ${ }^{49,66)}$. 促進型 VPC が dipyridamole により 抑制されたことは，これらのVPCの機序が DAD から起こる triggered activityである との推測を支持する所見と思われる.

また, 我々は 1 群抗不整脈剈の VPC に対 する効果を VPC-HR 関係と対比検討した. Diltiazem と atenolol はほとんど促進型 VPC のみを抑制したが45),51),52), mexiletine(図13) と disopyramide の VPC 抑制作用は促進型 と非促進型の間に有意差はなかった ${ }^{58), 63)}$.ま 
た diltiazem と atenolol の VPC 抑制効果は 投与期間が 2 週間から 4 週間と延長するにつ れて進行したが511,52), 1 群抗不整脈剤の VPC の抑制効果は 1 週間目と 2 週間目の間に差は なかった ${ }^{58), 63)}$.

\section{VPC に対する先行心拍数の蓄積効果}

$\mathrm{DAD}$ の振幅は刺激頻度のみならず刺激の

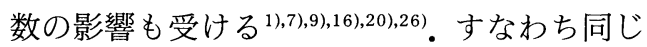
刺激頻度でも，刺激数の増加とともに DAD の振幅は増加し, triggered activity の発生頻 度も増加する (刺激の蓄積効果)。したがって, triggered activityに由来するVPCの発生 頻度は心拍数増加の程度のみならず，心拍数 増加の持続時間の影響も受けるものと期待さ れる(表 3, 判定基準 3 ).

図14は促進群の 1 症例の 24 時間心電図記録 から，心拍数が比較的急速な増加を示した時 間帯を選んで，心拍数と VPC の発生頻度の 時間経過を 3 分間隔でプロットしたものであ る ${ }^{45}$. 心拍数の増加 (矢印 $\mathrm{a}-\mathrm{d}$ ) と VPC の増加 との間には明らかな time lag が認められる。 図14 A は早朝の記録で, 心拍数増加前の心拍 数 (基礎心拍数) は $60 /$ 分以下と低く,短時間の 心拍数増加(矢印a)ではVPC はほとんど発

(A)

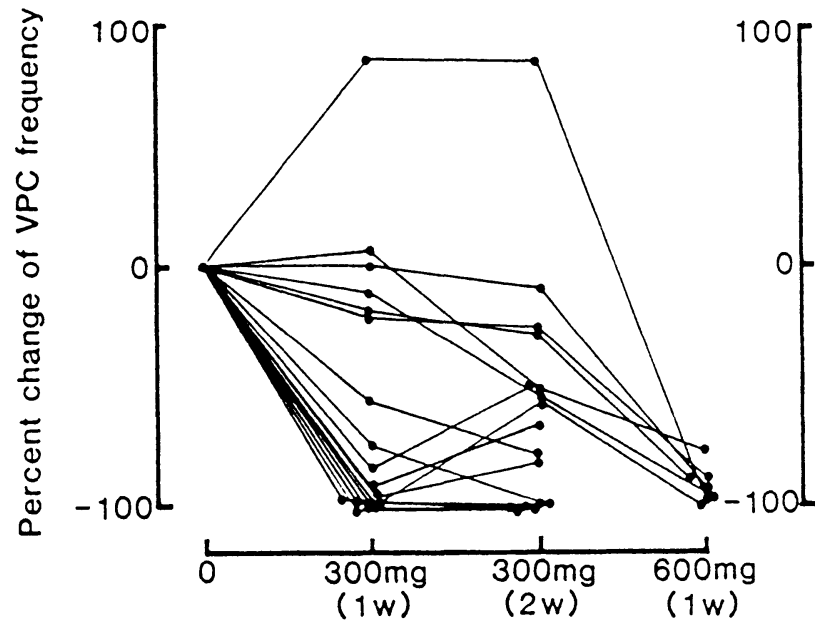

Duration of treatment (week)
生しなかった.しかし持続的心拍数増加(矢印 b)ではVPC が発生し，その頻度は次第に増 加した. 図14 B は午後 5 時前後の記録で，基 礎心拍数は約 $70 /$ 分と比較的高く, 心拍数増加 (矢印 $\mathrm{c}, \mathrm{d}$ ) の後, VPC の増加は短い time lag (3 分間)で起こっている.このような所見は, 促進型 VPC の増加は心拍数増加の二次的結 果であり, かつ, 先行心拍数はVPC に対して 蓄積効果をもつことを示唆する.

我々はVPC を頻発する 29 症例を対象とし て,VPC に対する心拍数増加の持続時間の影 響を解析し, diltiazem の VPC に対する効果 と対比した ${ }^{64)}$. 29例中, 促進群17例, 非促進群 12例であった. Diltiazem 投与前の24時間心 電図の記録から，次のような条件を満たす 10 分間(五つの連続する 2 分間)の記録を選び解 析した.すなわち，比較的低心拍数の 4 分間 に続いて,次の 6 分間は $10 /$ 分以上の心拍数増 加が持続するような時間帯を選んだ.

心拍数急上昇に伴う VPC 頻度の変化は増 加型 (14例, 図15 A C ), 平坦型 ( 9 例, 図15 D), および減少型 ( 6 例, 図15 E) の 3 型に分 類できた。ささらに増加型は二つのサブタイプ に分類できた。すなわち心拍数増加の持続時

(B)

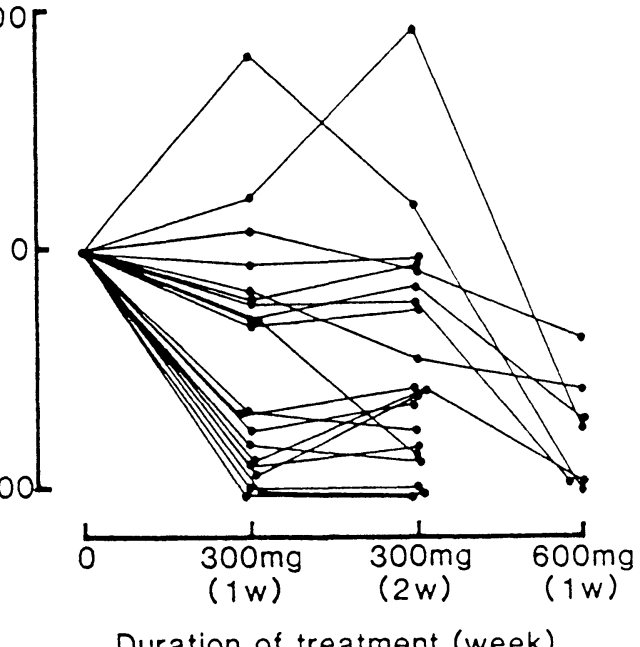

Duration of treatment (week)

図13 Mexiletine 投与による VPC 頻度の変化率

（文献58）ょり引用） 
(A)

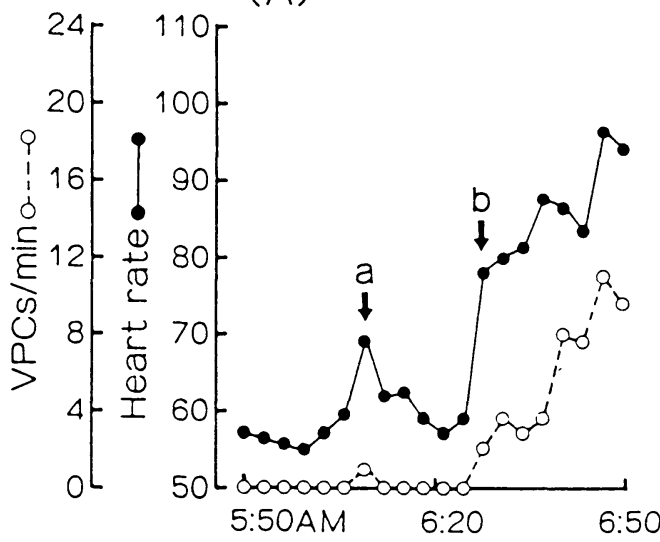

(B)

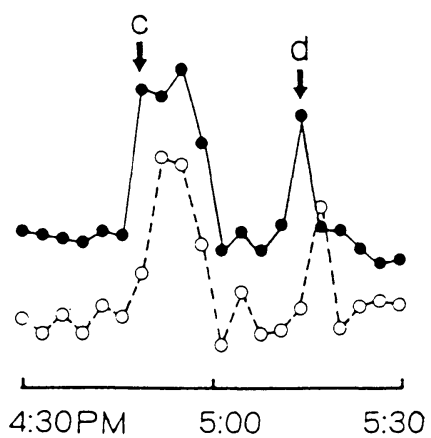

図14 促進群の 1 例にみられた心拍数の変化(黒丸)とVPC 頻度の変化(白丸)間の time lag

説明は本文参照のこと.

（文献45）より引用）

(A)

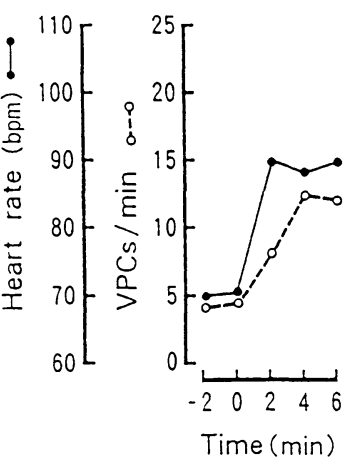

(B)
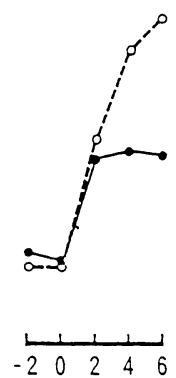

Time $(\mathrm{min})$
(C)

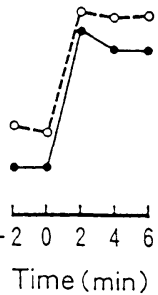

(D)

(E)

図15 持続的心拍数急上昇の (黒丸) に伴うVPC の発生頻度 (白丸)の変化の時間経過

$\mathrm{A}$ と $\mathrm{B}$ ：遅延増加型； $\mathrm{C}$ ：同時増加型； $\mathrm{D}$ ：平坦型； $\mathrm{E}$ ：滅少型. (文献64）より引用)

間が延長するにつれて VPC が増加し, 心拍 数増加よりも数分間遅れて VPC 頻度がピー クに達するもの（遅延増加型， 7 例，図15 A, B) と, 心拍数の増加と同時に VPC の増加が ピークに達するもの(同時増加型， 7 例，図15 C)である. Diltiazem は促進群17例中10例に 有効 (VPC 減少率>75\%)であったが, 非促進 群12例では全例に対して無効であった。しか も diltiazem は促進群のうち, 遅延増加型を 示す 7 例の全例に有効であったが，それ以外 の型の 10 例 (同時増加型 5 例と平坦型 5 例) で は 3 例にのみ有効であった. 非促進群 12 例中,
同時増加型 2 例，平坦型 4 例，減少型 6 例が みられ, 遅延増加型は 1 例もみられなかった。 $\mathrm{DAD}$ に対する先行刺激の蓄積効果は実験 条件によって異なる. Purkinje 線維や心室筋 におけるジキタリス誘発性 DAD の場合は, 刺激数の 10 15程度までの増加では DAD の 振幅が増加するが，それ以上刺激数を増加し ても振幅はほとんど変化しない(1),7),28).一方, Purkinje 線維におけるカテコラミン誘発性 の triggered activity ${ }^{23)}$, あるいは完全房室ブ ロックを作成したin vivo のイヌ心室におけ るジギタリス誘発性 triggered activityで JPN. J. ELECTROCARDIOLOGY Vol. 14 SUPPL. 21994 
$は^{34)}$, 刺激数を数個から 100 個以上へと増加す るにつれて誘発される activityの数も増加 する，促進型 VPCにみられた遅延増加の現 象は triggered activityに対する先行刺激の 蓄積効果と類似している. Reentry の誘発に おいても，ある程度刺激の数が影響する。し かし reentry の場合は，10～50個の刺激で誘 発できない場合は, 刺激数を 100 200個に増 加しても誘発はできない ${ }^{6)}$. また正常自動能 は高頻度刺激で抑制されるが2), 異常自動能 は比較的短時間の高頻度刺激では促進される ことがある ${ }^{27)}$. しかし十分長い期間(数分間) の高頻度刺激では異常自動能も抑制される ${ }^{27)}$. 以上のような考察を総合すると, 促進型 VPC にみられた遅延増加の現象は, reentry や自動能の機序では説明が困難であり, DAD から起こる triggered activityの特徵と一致 する所見のように思われる ${ }^{3,6), 51), 52), 64) . ~}$

\section{V . Triggered activity の臨床的同定 の問題点}

Triggered activity と臨床的不整脈の関係 については, 今後さらに検討すべき問題は多 い. Triggered activity の確実な証明には, $\mathrm{DAD}$ を直接記録することが必要であろう. 現在のところ, 患者の心臓から直接細胞内電 位を記録することはできない. 今後, 接触電 極法による monophasic action potential の 記録や mapping 法などによる検査, DAD に 対して特異的に有効な抗不整脈剤の開発など により, DAD と臨床的不整脈との関係が, 状 況証拠から確証に向かって近づくことが期待 される。

これまで，もし，ある患者の不整脈の機序 が DAD であるならば，その不整脈の pacing (心拍数)や種々の薬剤に対する反応は, 実験 的 DAD と同様の法則に従うであろうとの仮 定に基づいて，臨床的 triggered activityの 同定が試みられてきた. Pacing や Ca 拮抗薬 に対する DAD の反応はかなり特徵的ではあ るが, reentry や自動能(特に異常自動能) と overlap する部分もあり, 個々の症例につい て, triggered activity か否かを確実に診断す

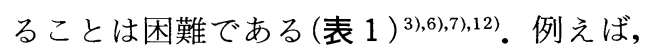
triggered activity は, reentry と同様, pacing による誘発・停止が可能である ${ }^{3), 6), 28)}$. 先行刺 激と不整脈の連結時間が triggered activity では正相関を示し, reentry では逆相関を示 すことが両者の重要な鑑別点である ${ }^{3), 6)}$. しか し triggered activityで逆相関を示し ${ }^{28), 30)}$, reentry で正相関を示す場合がある ${ }^{6)}$.また動 物実験と生体心臓の間に存在する大きな条件 の差異を考慮すれば，実験的 DAD の法則を そのまま臨床的不整脈に適用することにはき わめて慎重であらねばならない.

動物実験においては，DAD はジギタリス 中毒, 細胞外 $\mathrm{K}$ 濃度低下, 細胞外 $\mathrm{Ca}$ 濃度上 昇, 虚血・再灌流, 急性心筋梗塞などの異常 条件下で誘発される ${ }^{1,77,12), 13), 15)}$. 運動誘発性の 特発性 VT や促進型 VPC は, 臨床的 triggered activity の有力な候補と思われる. しか し，筆者ら ${ }^{45), 60), 64)}$ の検討では促進型 VPC の 症例は, 明らかな心疾患を有しないものも多 く, DAD を誘発・促進するような要因(ジギ タリス投与, 血清電解質異常など) を認めない ものがほとんどであった。また，DADによる と推測される特発性 VT の症例も, 心疾患の ない比較的若年者が多いと報告されている (表 2 ). Triggered activity が完全に正常な 心筋に発生することはないにしても, subclinical な軽度の心筋の異常においても，心 拍数の増加や交感神経緊張などの日常生活に 関連した諸因子の変動によって, DAD が誘 発される可能性が否定できない.

\section{VI.おわりに}

DAD ら起こる triggered activityと心 室性不整脈との関係について，これまでの報 告を紹介した. Triggered activity は reentry や自動能六進と同様, 臨床的不整脈の発生に 深く関与している可能性がある.しかし, triggered activity を確実に同定する臨床的方法 
は確立されていない.今後, 電気生理学的検 査法の進歩や DAD に特異的に有効な抗不整 脈剤の開発などによって, triggered activity を臨床的に確実に同定することが可能になれ ば，臨床不整脈の発生における DAD の役割 がさらに明確になり，また，その有効な治療 法の確立にも役立つものと思われる。

\section{〔文献〕}

Reviews

1) Ferrier GR: Digitalis arrhythmias: role of oscillatory afterpotentials. Prog Cardiovasc Dis $19: 459 \sim 474,1977$

2) Vassalle $M:$ The relationship among cardiac pacemakers. Overdrive suppression. Circ Res $41: 269 \sim 277,1977$

3 ) Rosen MR, Reder RF : Does triggered activity have a role in the genesis of cardiac arrhythmias? Ann Intern Med 94: 794 801, 1981

4 ) Reuter $\mathrm{H}:$ The slow inward current and its modulation by neurotransmitters. In : Paes de Calvalho A, Hoffman BF, Lieberman M, eds. Normal and abnormal conduction in the heart. Futura Publishing Co, New York, 277 286, 1982

5 ) Surawicz B : Role of calcium-blocking agents in treatment of cardiac arrhythmias related to myocardial ischemia. Am Heart J 103 : 698 706, 1982

6 ) Burgada P, Wellens HJJ : The role of triggered activity in clinical ventricular arrhythmias. PACE $7: 260 \sim 271,1984$

7) Wit AL, Rosen MR : Afterdepolarizations and triggered activity. In : Fozzard HA, Haber E, Jennings RB, Katz AM, Morgan HE, eds. The heart and cardiovascular system. New York, Raven Press, 1449 1490, 1986

8 ) Gorgels APM, Vos MA, Burgada P, Wellens HJJ : The clinical relevance of abnormal automaticity and triggered activity. In : Brugada P, Wellens HJJ, eds. Cardiac arrhythmias : where to go from here?. Futura Publishing Co, New York, 147 169, 1987

9 ) 平岡昌和, 川野誠子, 平野裕司, 桜田春水: Triggered activity (誘発活動) と不整脈。心臟 19 : $760 \sim 769,1987$

10）有田 眞：歩調取り電位と一過性脱分極. 心電図 $8: 271 \sim 279,1988$
11）飯沼宏之：抗不整脈薬としての Ca 拮抗薬. 心電 図 8(suppl 2)：37〜 53, 1988

12) Cranefield PF, Aronson RS : Cardiac arrhythmias: The role of triggered activity and other mechanisms. Futura Publishing Co, New York, Monograph, 1988

13) Janse MJ, Wit AL:Electrophysiological mechanisms of ventricular arrhythmias resulting from myocardial ischemia and infarction. Physiol Rev 69: 1049 1169, 1989

14) Lerman BB, Belardinelli L : Cardiac electrophysiology of adenosine. Circulation 83 : 1499 1509, 1991

15）山崎 昇：再灌流不整脈: $\mathrm{Ca}^{2+}$ overload とフリ ーラジカル. 心電図 11 (suppl 2)：49〜 72, 1991

Originals : experimental studies

16) Ferrier GR, Saunders JH, Mendez C : A cellular mechanism for the generation of ventricular arrhythmias by acetylstrophanthidin. Circ Res $32: 600 \sim 609,1973$

17) Hashimoto K, Moe G: Transient depolarizations induced by acetylstrophanthidin in specialized tissue of dog atrium and ventricle. Circ Res $32: 618 \sim 624,1973$

18) Ferrier GR, Moe GK : Effect of calcium on acetylstrophanthidin-induced transient depolarizations in canine Purkinje tissue. Circ Res $33:$ 508 515, 1973

19) Kass RS, Lederer WJ, Tsien RW, Weingart $\mathrm{R}$ : Role of calcium ions in transient inward currents and aftercontractions induced by strophanthidin in cardiac Purkinje fibers. J Physiol 281: 187 208, 1978

20) Hiraoka M, Okamoto $Y$, Sato $T$ : Oscillatory afterpotentials in dog ventricular muscle fibers. Cric Res 48:510 518, 1981

21) Mary-Rabine L, Hordof AJ, Danilo P, Malm JR, Rosen MR : Mechanisms for impulse initiation in isoloted human atrial fibers. Circ Res $47: 267 \sim 277,1980$

22) Rosen M, Danilo P : Effects of tetorodotoxin, lidocaine, verapamil, and AHR-2666 on ouabain-induced delayed afterdepolarizations in canine Purkinje fibers. Circ Res 46: $117 \sim 124,1980$

23) Wald RW, Waxman MB : Pacing-induced automaticity in sheep Purkinje fibers. Circ Res $48: 531 \sim 538,1981$

24) Matsuda H, Noma A, Kurachi $Y$, Irisawa H : Transient depolarization and spontaneous voltage fluctuations in isolated single cells from guinea pig ventricles. Calcium-mediated 
membrane fluctuations. Circ Res 51: 142 151, 1982

25) Dangman KH, Danilo P, Hordof AJ, MaryRabine L, Reder RF, Rosen MR: Electrophysiologic characteristics of human ventricular and Purkinje fibers. Circulation $65: 362 \sim 368,1982$

26) El-Sherif N, Gough WB, Zeiler RH, Mehra $\mathrm{R}$ : Triggered ventricular rhythms in 1-dayold myocardial infarction in the dog. Circ Res $52: 566 \sim 579,1983$

27) Dangman KH, Hoffman BF : Studies on overdrive stimulation of canine cardiac Purkinje fibers: Maximal diastolic potential as a determinant of the response. J Am Coll Cardiol 2: 1183 1190, 1983

28) Moak JP, Rosen MR : Induction and ternination of triggered activity by pacing in isolated canine Purkinje fibers. Circulation 69: $149 \sim 162,1984$

29) Gorgels APM, Wit B, Beekman HDM, Dassen WRM, Wellens HJJ : Triggered activity induced by pacing during digitalis intoxication: observations during programmed electrical stimulation in the conscious dog with chronic complete atrioventricular block.PACE $10: 1309 \sim 1321,1987$

30）今西愿, 迫 秀則, 木村龍範, 有田 眞, 調 亟治, 葉玉哲生：病的七ト心房筋の異常自動能：pacing の効果. 心電図 $8: 289 \sim 294,1988$

31) Priori SG, Mantica M, Schwartz PJ : Delayed afterdepolarizations elicited in vivo by left stellate ganglion stimulation. Circulation 78 : 178 185, 1988

32) Iinuma $H$, Sekiguchi $A$, Kato $K$ : The response of digitalized canine ventricle to programmed stimulation: a study on triggered activity arrhythmias in the whole heart. PACE 12: 1331 1346, 1989

33) Furukawa T, Kimura S, Castellanos A, Bassett AL, Myerburg RJ : In vivo induction of "focal" triggered ventricular arrhythmias and responses to overdrive pacing in the canine heart. Circulation $82: 549 \sim 559,1990$

34) Vos MA, Gorgels APM, Leunissen DM, van Deursen RTAM, Wellens HJJ : Significance of the number of stimuli to initiate ouabaininduced arrhythmias in the intact heart. Circ Res $68: 38 \sim 44,1991$

35) Song Y, Thedford S, Lerman BB, Belardinelli $\mathrm{L}$ : Adenosine-sensitive afterdepolarizations and triggered activity in guinea pig ventricular myocytes. Circ Res 70:743 753, 1992
Originals : clinical studies

36) Zeipes DP, Foster PR, Troup PJ, Pederson $\mathrm{DH}$ : Atrial induction of ventricular tachycardia: reentry versus triggered automaticity. Am J Cardiol 44:1 8, 1979

37) Rosen MR, Fisch C, Hoffman BF, Danillo P, Lovelace DE, Knoebel SB: Can accelerated atrioventricular junctional escape rhythms be explained by delayed afterdepolarizations?. Am J Cardiol 45: 1272 1284, 1980

38) Wu D, Kou H, Hung $J$ : Exercise-triggered paroxysmal ventricular tachycardia. A repetitive rhythmic activity possibly related to afterdepolarization. Ann Intern Med 95: 410 414, 1981

39) Winkle RA:The relationship between ventricular ectopic beat frequency and heart rate. Circulation 66:439 446, 1982

40) Sung RJ, Shapiro WA, Shen EN, Morady F, Davis $\mathrm{J}$ : Effects of verapamil on ventricular tachycardias possibly caused by reentry, automaticity, and triggered activity. J Clin Invest $72: 350 \sim 360,1983$

41) Nau GJ, Aldariz AE, Acunzo RS, Elizari MV, Rosebaum MB : Clinical studies on the mechanism of ventricular arrhythmias. In : Rosenbaum MB, Elizari MV, eds. Frontiers of cardiac electrophysiology. The Hague, Martinus Nijhoff, 239 273, 1983

42) Coumel P, Leslerq JF : Role of the autonomic nervous system in the genesis of clinical arrhythmias. In : Rosenbaum MB, Elizari MV, eds. Frontiers of cardiac electrophysiology. The Hague, Martinus Nijhoff, 552 581, 1983

43) Woelfel A, Foster JR, Simpson RJ, Gettes LS : Reproducibility and treatment of exercise-induced ventricular tachycardia. Am J Cardiol $53: 751 \sim 756,1984$

44) Woelfel A, Foster JR, McAllister RG, Simpson RJ, Gettes LS : Efficacy of verapamil in exercise-induced ventricular tachycardia. Am J Cardiol 56:292 297, 1985

45) Ito M, Maeda $Y$, Arita M, Ito S, Saikawa T, Omura I, Fujino T, Fukumoto T, Kikuchi Y, Yamada K, Yanaga $T$ : Effects of oral diltiazem on ventricular premature contractions. J Electrocardiol $19: 59 \sim 66,1986$

46) Shenoy MM, Hariman RJ, Balla S, Punatar HK : Triggered activity as a possible mechanism of ventricular tachcyardia in mitral valve prolapse. Am Heart J $112: 1339 \sim 1342$, 1986

47) Ohe T, Shimomura K, Matsuhisa M, Kama- 
kura S, Shimizu A, Aihara N, Sato I, Nakajima $\mathrm{K}$ : The electrophysiological characteristics of various types of paroxysmal tachycardias. Jpn Circ J 50 : 99 108, 1986

48) Kasanuki H, Ohnishi S, Tanaka E, Hirosawa $\mathrm{K}$ : Idiopathic sustained ventricular tachycardia responsive to verapamil: clinical electrocardiographic and electrophysiologic considerations. Jpn Circ J 50 : 109 118, 1986

49) Lerman BB, Belardinelli L, West GA, Berne RM, DiMaco JP: Adenosine - sensitive ventricular tachycardia: evidence suggesting cyclic AMP-mediated triggered activity. Circulation $74: 270 \sim 280,1986$

50) Zimmermann M, Maisonblanche P, Cauchemez B, Leclerq J, Coumel P : Determinants of the spontaneous ectopic activity in repetitive monomorphic idiopathic ventricular tachycardia. J Am Coll Cardiol $7: 1219 \sim 1227$, 1986

51) Ito $M$, Tsumabuki $S$, Maeda $Y$, Arita $M$, Saikawa T, Ito S, Fujino T, Fukumoto T, Yamada K, Kikuchi Y: Suppression of ventricular premature contractions possibly related to triggered activity by oral diltiazem and atenolol. Jpn Circ J 51：217〜229, 1987

52）伊東盛夫, 妻夫木茂, 前田泰宏, 有田 眞, 犀川哲 典, 伊東祐信, 藤野武彦, 福本晃雄, 山田賢典, 菊池 裕, 佐伯和之, 石原保之：24時間心電図法 を用い, triggered activityによると思われる心 室性期外収縮を同定する試み。心臓 19：777〜 786,1987

53）藤井 隆, 大江 透, 益田元子, 鎌倉史郎, 松久茂 久雄, 下村克朗：迷走神経刺激にて停止しえた 心室頻拍の一例. 心電図 $7: 663 \sim 668,1987$

54) Tsumabuki S, Ito $M$, Arita $M$, Saikawa $T$, Ito $\mathrm{S}$ : Day-to-day variation of the frequency of ventricular premature contractions depends on variation of heart rates. Jpn Circ J 52 : 1231 1239, 1988

55) Bhandari A, Hong RA, Rahitoola SH : Triggered activity as a mechanism of recurrent ventricular tachycardia. $\mathrm{Br}$ Heart J 59 : 501 505, 1988

56) Ohe T, Shimomura K, Aihara N, Kamakura S, Matsuhisa M, Sato I, Nakagawa H, Shimizu A : Idiopathic sustained left ventricular tachycardia: clinical and electrophysiologic characteristics. Circulation $77: 560 \sim 568,1988$

57）猪岡英二, 清水芳雄：先行 $R R$ 間隔/連結期関係 からみた心室性期外収縮の臨床的評価法. 心電図 8:145 150, 1988

58）中川幹子, 犀川哲典, 伊東祐信, 伊東盛夫：心室
性期外収縮に対する mexiletine の短期および長 期経口投与の効果 : 期外収縮頻度の心拍数依存 性との対比. 心電図 9:307〜316, 1989

59) Ritchie AH, Kerr CR, Qi A, Yeung-Lai-Wah JA : Nonsustained ventricular tachycardia arising from the right ventricular outflow tract. Am J Cardiol $64: 594 \sim 598,1989$

60) Inoue $T$, Koumatsu K, Ito M, Arita M, Saikawa $\mathrm{T}$ : Heart rate-dependent alteration of the frequency and coupling interval of ventricular arrhythmias as measured by 24 hour ECG mositoring. Jpn Circ J 55 : 942 950, 1991

61) Fujimoto $Y$, Hirokane $Y$, Doi T, Fukuki M, Kotake H, Mashiba H : Relathonship between ventricular premature contraction frequency and heart rate evaluated by Holter monitoring and treadmill test. J Ambulatory Monitoring $4: 187 \sim 197,1991$

62）小林洋一, 富田 彰, 千和田和美, 中川陽之, 丹野 郁, 蔵野康造, 菊嶋修示, 矢沢 卓, 馬場隆男, 向 井秀之, 片桐 敬：心室性期外収縮の機序推定に 対する dipyridamole の有用性の検討。心電図 $11: 581,1991$

63) Saikawa $T$, Nakagawa $M$, Takahashi $N$, Ishida S, Fujino T, Ito M, Shimoyama N, Hara M, Yonemochi H, Maeda T, Takaki R, Arita M, Tsumabuki S: Mexiletine and disopyramide suppress ventricular premature contractions (VPC) irrespective of the relationship between the VPC and the underlying heart rate. Jpn Heart J 33 : 665 678, 1992

64) Koumatsu K, Ito $M$, Fujino $T$, Saikawa $T$, Arita $\mathrm{M}$ : Cumulative effects of heart beat on ventricular premature contractions suggesting possible involvement of triggered activity. Jpn Circ J 57 : 503 511, 1993

65) Wilber DJ, Baerman J, Olshansky B, Kall J, Kopp D : Adenosine-sensitive ventricular tachycardia. Clinical characteristics and response to catheter ablaton. Circulation 87 : 126 134, 1993

66) Lerman $\mathrm{BB}$ : Response of nonreentrant catecholamine-mediated ventricular tachycardia to endogenous adenosine and acetylcholine. Evidence for myocardial receptor-mediated effects. Circulation $87: 382 \sim 390,1993$

67) Mitrani RD, Klein LS, Rardon DP, Hackett FK, Zeipes DP, Miles WM : Ventricular tachycardia originating in the right ventricular outflow tract is usually not due to afterde polarizations. Circulation 88(suppl, part 2): I-460, 1993 